\title{
Integrity review halted
}

\section{Washington}

LAST July, while congressional investigators were grilling the US National Institutes of Health for their failing scientific misconduct policies, another biomedical agency - the Food and Drug Administration (FDA) - was quietly starting a review of its own integrity procedures, hoping to catch the flaws before Congress did.

But now the FDA review has itself run into trouble. Last month, just nine weeks after the agency issued a $\$ 710,558$ contract to a Washington law firm to run the review, it was forced to cancel the contract when the congressional investigative committee of Representative John Dingell (Democrat, Michigan) launched an investigation into possible conflict of interest at the winning firm, Washington-based Shaw, Pittman, Potts \& Trowbridge.

Now, on top of a continuing probe into data-integrity lapses that have allowed drug companies to submit spurious products and clinical trial results (typified by last year's generic drug scandal), the Dingell committee is investigation how the agency could have awarded the integrity-review contract to a law firm that was simultaneously representing major FDA clients and had bragged that the contract would help it to get those clients through the system.

According to contract documents, FDA had decided to bring in outside help because staff and resource shortages have forced the agency "to rely more heavily on entities submitting data to it to police themselves" - a system that, FDA admitted, "has not always worked as well as it should." The agency receives more than 150,000 submissions for new drugs, medical devices, food additives and the like each year, and most applications are accompanied by supporting data to demonstrate safety and efficacy. In some cases - as an FDA investigation of a faulty artificial heart valve last year proved those data are sometimes intentionally incomplete, misleading, and even fabricated.

FDA hoped that going to a private law firm for an "integrity review" might convince Dingell and other congressional watchdogs that it was serious about reforming itself. But picking Shaw, Pittman as that firm appears to have only made the matter worse.

In an article published on 2 September, the trade journal Legal Times revealed that, far from being conflict-free, Shaw, Pittman has major pharmaceutical and food companies (including Monsanto, Dow Chemical and RJR Nabisco) as its clients. J. Thomas Lenhart, one of the parteners, told Legal Times that investigating FDA's data integrity procedures would "give us a chance to leam more about a substantial area of legal work....It may well open up new professional opportunities in the future."

The firm claimed that, because it lobbied for the companies, rather than directly handling their FDA applications, there was no conflict. But Dingell was unpersuaded, especially when he learned that the firm was also behind a new group - known as the Workplace Health and Safety Council - intended to oppose the strengthening of occupational health and safety laws. "It's a hugely embarrassing mess," says one Dingell staff member.

Within a week of the article, the Dingell committee had sent a letter to FDA, requesting all documentation on the contract awarding process and the integrity review. Committee staff then interviewed the FDA officials in charge of the review project. On 30 September, FDA gave in. It cancelled the contract and announced that it would finish the review internally.

Although Dingell staff have not planned a hearing on the case, they are looking into both the handling of the contract and the relationship between FDA and Shaw, Pittman. The case "exposed the vagaries of Washington deal-making," says a staff member. Whether that went as far as "an arrangement to give FDA a Good Housekeeping seal of approval", the staffer adds, will be the focus of the continuing investigation.

Christopher Anderson

\section{Social science gets its day}

\section{Washington}

AFTER years of lobbying for their own directorate at the US National Science Foundation (NSF), social and behavioural scientists have finally been granted their wish. NSF last week announced that it is ending the second-class status of these disciplines in the current directorate for Biological, Behavioral, and Social Sciences (BBS) by splitting off a new $\$ 70$ million Social, Behavioral and Economic Sciences directorate. Completing the name game, BBS will become simply the directorate for Biological Sciences. NSF director Walter Massey said he hoped that having a directorate of their own will mean "more clout" for both disciplines, but did not announce a major funding increase in either area. The Consortium of Social Science Association last week hailed the changes as a long overdue effort to remove social and behavioural sciences from the "long shadow" of biology at NSF.

Christopher Anderson

\section{Healy back on the beat}

\section{Washington}

HoPING to speed misconduct reforms at the US National Institutes of Health (NIH), assistant secretary for health James Mason last week returned NIH director Bernadine Healy to the driver's seat. Healy had withdrawn herself from decisions affecting the NIH Office of Scientific Integrity (OSI) after it emerged that OSI was investigating a researcher who had worked under her at her former institute, the Cleveland Clinic Foundation (see Nature 352, 461; 8 August 1991).

Explaining that the six to seven months remaining of the Cleveland Clinic investigation was too long to be without Healy's help, Mason transferred the case to the Office of Scientific Integrity Review (OSIR) in NIH's parent agency, the Department of Health and Human Services.

Just how OSIR will handle the case is not clear; the office, which is set up to review OSI investigations and assign penalties in a trial-like setting, has no investigators of its own, nor any experience in the art of hands-on investigating. Predictably, the investigations committee of Representative John Dingell (Democrat, Michigan) is planning a letter of protest.

C.A.

NUCLEAR WASTE STORAGE

\section{WIPP put on hold}

\section{Washington}

THE US Department of Energy (DOE) has backed down from a decision to begin shipping nuclear waste to its Waste Isolation Pilot Plant (WIPP) in New Mexico after the state's attorney general filed a lawsuit to stop the shipment. DOE had announced two weeks ago (Nature 353, 487; 10 October 1991) that WIPP was ready to be put into operation and that the energy department would not wait any longer for Congress to approve legislation on the last step needed to open the waste site - the transfer of the land to DOE.

But last week, after the state of New Mexico and environmental activists filed lawsuits, DOE reversed itself. Halting the process until a US court hears the New Mexico case on 15 November, "will help ensure that legal issues are resolved prior to our first shipment from the Idaho National Engineering Laboratory," Secretary of Energy James Watkins said.

Watkins was more conciliatory last week than the week before, when he had threatened to cancel $\$ 63$ million in payments to the state if it filed suit; now he has assured the New Mexico governor of "the department's financial and environmental commitments to the State of New Mexico".

Robert Pool 